University of Minnesota Morris Digital Well

University of Minnesota Morris Digital Well

\title{
Making the Invisible Visible: The Presence of Older Women Artists in Early Modern Artistic Biography
}

Julia K. Dabbs

University of Minnesota, Morris, dabbsj@morris.umn.edu

Follow this and additional works at: https://digitalcommons.morris.umn.edu/arthistory

Part of the Ancient, Medieval, Renaissance and Baroque Art and Architecture Commons, and the Women's Studies Commons

\section{Recommended Citation}

Dabbs, Julia K. "Making the Invisible Visible: The Presence of Older Women Artists in Early Modern Artistic Biography." Ageing Women in Literature and Visual Culture. Eds. Cathy McGlynn, Margaret O'Neill and Michaela Schrage-Früh. Springer/Palgrave Macmillan, 2017. 23-40.

This Book Chapter is brought to you for free and open access by the Faculty and Staff Scholarship at University of Minnesota Morris Digital Well. It has been accepted for inclusion in Art History Publications by an authorized administrator of University of Minnesota Morris Digital Well. For more information, please contact skulann@morris.umn.edu. 
Making the Invisible Visible: The Presence of Older Women Artists in Early Modern Artistic Biography

[final formatted version for publication in Ageing Women in Literature and Visual Culture, Palgrave Macmillan, 2017]

Julia K. Dabbs

\section{Introduction}

In the early modern period (i.e., from 1400-1800), professional women artists were greatly outnumbered by their male counterparts given that women were typically deterred from working, training, or being educated outside the home. Women were also perceived as lacking the necessary physical strength, and the intelligence, to succeed as fine artists (Boccaccio 2001, 251). Yet, we do know of successful women artists from this period, such as Artemisia Gentileschi and Sofonisba Anguissola, thanks not only to the scholarly efforts of modern-day art historians, but also the writings of early modern artistic biographers. These authors included life stories of selected remarkable women in their collected "lives of the artists," i.e. biographical compendia that were published throughout Europe following the popular success of Giorgio Vasari's Le vite de' più eccellenti pittori, scultori, e architettori (1550). Like their hagiographical antecedents, the characterizations of artists were to a certain extent formulaic in order to fit the mould of what that culture considered an exemplary individual. Thus, the female artist was, regardless of the facts, stereotypically characterized as young, virtuous, and beautiful - the three "graces" associated with women of the period. ${ }^{1}$

Acknowledgment: support for this project was made possible by an Imagine Fund Award from the University of Minnesota. 
Did this emphasis on youth and beauty mean, then, that women artists who continued to create art into middle age, or later, were ignored by male biographers? Recent scholarship suggests that this indeed was the case; for example, in her essay on "Old Women in Early Modern Europe," Lynn Botelho writes: "Finally, given the gendered construction of early modern Europe, there were few active women artists, and fewer still whose late life-style could be analysed and consequently our understanding of the artist in old age is overwhelmingly male" (Botelho 2013, 306). Indeed, a review of the literature to date would reasonably give one that impression, since studies such as Philip Sohm's The Artist Grows Old: The Aging of Art and Artists In Italy 1500-1800 (2007) or Thomas Dormandy's Old Masters: Great Artists in Old Age (2000) only peripherally mention a few women artists who worked into their later years.

However, as I will argue, this absence of the elder woman artist from more recent historical studies of the subject is not because there were few women who continued to work until later in life. Indeed, of the 46 women artists included in my anthology, Life Stories of Women Artists 1550-1800, at least one-third are described as creating art past the age of $50 .^{2}$ Further research will likely show that this number is just the tip of the iceberg, for at least 52 early modern women artists whose life dates are known with some certainty lived beyond 50

\footnotetext{
${ }^{1}$ See Baldesar Castiglione, The Book of the Courtier, trans. George Bull (New York: Penguin, 1967) 211, for the association of women with virtue and beauty; and for the youthful stereotype, it is only necessary to glance through a catalogue on Renaissance portraiture, such as David Alan Brown, Virtue \& Beauty (Washington D.C.: National Gallery of Art, 2001). The "formula" for female artists was largely set by Vasari, who writes of sculptor Properzia de' Rossi that she was "a young woman" who not only was a talented homemaker and musician, but also "very beautiful," even though the portrait of de'Rossi that accompanies her life story suggests otherwise (in Dabbs 2009, $56)$.

${ }^{2} 50$ years of age, according to Botelho $(2013,301)$, is an approximate number used to mark "cultural old age" in the early modern period, so it is being used here.
} 
years of age. Thus, one intention of this chapter is to reverse the current misapprehension of the longevity of early modern women artists, and render these "invisible" elder women creators more visible. Yet in addition, I will consider how the woman artist was characterized by her biographer in old age, and provide some comparison with literary tropes associated with elder male artists of the period, to see to what extent gender may have factored into cultural perceptions and attitudes towards old age.

\section{Old Age Tropes in the Life Story of the Male Artist}

"I am an old man and death has robbed me of the dreams of youth - may those who do not know what old age means bear it with what patience they may when they reach it, because it cannot be imagined beforehand" (Sohm 2007, 3). So wrote Michelangelo Buonarroti in a letter of 1547, when he was 72 years of age. Although Michelangelo's comments may seem especially harsh, they did find echoes in the early modern period. Indeed, old age and its inevitable illnesses were characterized as "fierce, powerful enemies" by the seventeenth-century artistic biographer, Domenico Bernini (Bernini 2011, 231). Another biographer, the former painter Carlo Ridolfi, stated that particularly for the artist, old age "brings great annoyance and infirmity and is unsuitable for working" (in Sohm 2007, 24).

Given this predominantly negative attitude towards old age, it is unsurprising that early modern biographers generally give little attention to the end of an artist's life, whether they be male or female, famous or infamous. To some degree, this was because early modern 
biographers, whose literary genre was primarily epideictic in nature, ${ }^{3}$ likely would have little to praise given the inevitable decline of the artist's abilities and/or physical condition as he or she aged. Indeed, as Campbell and Sohm have affirmed in their studies of older male artists of the early modern period, the end of life experiences are often negatively cast (Campbell 2002, 322; and Sohm 2007, 19-35). As Sohm relates, "Art biographers of elderly artists repeated the same story, dismal in its sameness: eyesight fades; reflexes and coordination slacken; the hand trembles" (Sohm 2007, 4). For the visual artist, dependent on physical action in order to express his or her ideas, this corporeal deterioration was often devastating. Should his eyesight become compromised, as was the case for Giovanni Paolo Lomazzo, his ability to create art was finished. Should his hands become arthritic, or overcome by tremors, or his eye-hand coordination lessen, he might still be able to paint, but with diminished skill or ability to delineate detail. For some artists, this decline could lead to a loss of patronage, and subsequent impoverishment (Sohm 2007, 26). Even celebrated artists such as the Venetian painter Titian were not immune from criticism when their style changed in old age. Vasari states in his life story of Titian that "it would have been well for him in these his last years not to work save as a pastime, so as not to diminish with works of less excellence the reputation gained in his best years, when his natural powers were not declining and drawing towards imperfection" (Vasari 1996, II, 798). Or as the seventeenth-century sculptor Gian Lorenzo Bernini put it, upon viewing a painting by the French master Nicolas Poussin, "there comes a time when one should cease work, for there is a falling off in everyone in old age" (in Sohm 2007, 71).

\footnotetext{
${ }^{3}$ Rubin 1990, 36. Here Rubin discusses the "oratory of praise" or epideictic approach used in Vasari's Lives of the Artists, but this rhetorical manner was certainly followed by other biographers of the early modern period.
} 
Of course the problem, then as now, was not being able to admit that one had declining abilities or stamina. For some older artists, as Vasari relates in the life stories of Beccafumi and Pontormo, this could result in death due to overwork at an advanced age (Vasari 1996, II, 203 and 371). However, biographers could put a positive spin on such denials of physical limitations. For example Bernini, at the age of 82 , insisted on climbing up and down a ladder himself in order to help fix a structurally unsound building as requested by the Pope; this over-exertion was later blamed for weakening the artist's body, leading shortly thereafter to his death (Bernini 2011, 227 and 231). But for Bernini, it was a matter of pride - he couldn't refuse the Pope, or leave the work to someone potentially less capable. His enactment of what we might call "heroic old age," overcoming or at least not succumbing to physical barriers that would intimidate others his age, thus gave the biographer a climactic chance to gain the reader's sympathy and admiration. ${ }^{4}$

Besides the loss of physical functionality, a pervasive concern regarding ageing in modern times is the demise of intellectual functionality. However, this type of decline rarely surfaces in early modern artistic biography; instead, intellectual competence and acuity in old age are emphasized. Teaching or writing about art are often mentioned as compensatory activities for the artist who could no longer physically create art (Campbell 2002, 330 and Sohm 2007, 75). In this respect, the biographer was able to draw upon the commonly held positive association between old age and wisdom during the early modern period..$^{5}$ A cogent example is found in Bernini's life

\footnotetext{
${ }^{4}$ Another example of "heroic old age" can be found in Vasari's vita of the early Renaissance master Luca Signorelli, in which he assists with a fresco project at the age of 82, even though hindered by paralysis (1996, I: 61314).
} 
story, where his son states that his father's clarity of intellect was not obfuscated by old age or illness. Domenico then relates that his father even devised a method of sign language so that he could still communicate with those around him when, close to death, he was no longer able to speak: "for everyone it was now a cause of wonder how well he could communicate with the priest merely by the movement of his left hand and eyes. This was indeed a clear sign of that great liveliness of spirit of his, which not even then, when his life was failing, showed any sign of surrender" (Bernini 2011, 232). Bernini's ability to overcome this disability by means of his intellectual acuity can thus serve as another manifestation of "heroic old age" evidenced in artistic biography.

The passage above concerning Bernini's last days, in addition to additional description by his son Domenico, emphasise two other key concepts associated with biographical descriptions of ageing: the psychological and spiritual conditions of the individual. In the early modern period, the life stage of old age in men was associated with melancholia, given the belief that psychological states were related to one's physiological condition - thus as the body became cold and dry due to ageing, so one's temperament would inevitably tend towards melancholy. ${ }^{6}$ For some older artists such as Pontormo, who became overwrought by negative feelings concerning their work, this extreme form of melancholia could be attributed as a cause of death (Vasari 1996, II, 371).

\footnotetext{
5 See for example Castiglione's The Courtier (1528), in which old men are advised to "make use of the prudence and knowledge they will have acquired through their long experience, act like oracles to whom everyone will turn for advice" (Castiglione 1967, 123). On this point see also Campbell 2002, 321 and 330.

${ }^{6}$ Sohm 2007, 97-98. For a helpful explanation of humoral theory, especially as it related to melancholia, see Dixon 2013, 11-13.
} 
Bernini, in contrast, is shown by his biographer to once again act heroically in the face of death, this time expressed by his emotional resoluteness and fervent faith: "In talking of death, he would do so not with the distress and horror that is usual among old people, but with an incomparable steadfastness of spirit, ever reminding himself of its approach so as to prepare to meet it properly" (Bernini 2011, 230). As Sohm relates, there are numerous other examples of older (male) artists who exhibit this kind of heightened spirituality, which might be expressed in their artwork, as well as in their behaviour (Sohm 2007, 69-71).

In this brief overview, then, we have shown that both positive and negative tropes can be found in the life stories of male artists as they age. The most common negative trope is the inevitable physical decline and its impact on art. However, this physical loss could be countered to some extent by exemplary or heroic reactions to this decline, such as an increased emphasis on intellectual acuity, or emotional or spiritual strength. As will be shown, on occasion this latter trope can also be found in life stories of women artists, yet we shall also encounter other themes that occur more uniquely in regards to elder female creators, which I believe demonstrates that there wasn't a standardized biographical approach to writing the artist's life in old age.

\section{Old Age Tropes in the Life Story of the Female Artist}

For the early modern artistic biographer, writing about an elder female artist was an inherently more challenging task compared to characterizing an elder male artist. Reasons for this involved the general nature, as well as more specific physical and emotional properties associated with older women in this period. First, there was the lingering negative cultural stereotype of the older 
woman as witch, crone, or hag (Botelho 2013, 297, 305). As Botelho states in her survey of the subject, "Given the patriarchal nature of the early modern world, cultural constructions of aged females, particularly those expressed in literature, were heavily weighted towards the negative" (Botelho 2013, 305). In art of the period, the old woman often performed the role of lower-class servant, whose weather-beaten and desiccated body was used as a point of contrast to the beautiful, ivory-skinned young lady who was the focus of the painting (as seen for example in Caravaggio's Judith Beheading Holofernes, Rome, Galleria Nazionale d'Arte Antica). Even in the hands of a woman artist, the old woman could be a subject for ridicule and scorn, as we see in Sofonisba Anguissola's drawing of Old Woman Studying the Alphabet with a Laughing Girl (Fig. 1). As Perlinghieri has suggested, the older woman was likely a servant of the Anguissola family (Perlingieri 1992, 44), and so one purpose of the drawing was for Sofonisba to practice her observational skills, particularly when it came to portraying different ages of women. Yet the artist has chosen to not just portray physical difference, but also intellectual difference as the young woman attempts to teach the elder woman. From a positive perspective, Anguissola does show the old woman trying to become literate; however, the activity seems rather fruitless and farcical, given that the young woman has to literally guide the elder woman's hand over the page, as if she were reading braille. The cultural stereotype of the old woman as simple, unintelligent, and physically impaired is ultimately reinforced. Indeed, the old woman stereotype was a difficult hurdle for artists and biographers to overcome.

\section{Fig. 1: Sofonisba Anguissola, Old Woman Studying the Alphabet with a Laughing Girl, 1550s} (Florence, Uffizi; Mondadori Portfolio/Art Resource, NY) 
Another challenge for the early modern artistic biographer in writing about the older woman artist was the stereotypical view of the female creator as young and beautiful, such that she was said to embody the beauty of her creations (Sohm 2007, 20). Some Renaissance men made this connection quite directly; an admirer of Sofonisba Anguissola wrote that "There is nothing that I desire more than the image of the artist herself, so that in a single work I can exhibit two marvels, one the work, the other the artist" (qtd. In Chapman 2013, 198). However, as Germaine Greer warned in her groundbreaking book, The Obstacle Race: The Fortunes of Women Painters and Their Work (first published in 1979), "Young women grow old; . . If the female painter shows herself a serious rival to men, committed to advancing her own career and not simply playing, she may expect opposition to harden against her" $(2001,88)$. One form of opposition was to ridicule the physical appearance of older female subjects. The eighteenthcentury pastellist, Rosalba Carriera, was repeatedly derided for her lack of beauty as she aged; for example, Emperor Charles VI of Austria was said to remark to a court artist after being introduced to Carriera, then age 55, that "She may well be worthy... but she is very ugly" (in Dabbs, 2008, 37, note 20). Another eighteenth-century artist, the German painter Anna Dorothea Therbusch, was harshly criticized for her perceived physical and social deficiencies by the influential art writer, Denis Diderot: "It was not charm that she lacked, it was not talent that she lacked in order to create a great sensation in this country, ... it was youth, it was beauty, it was modesty, it was coquetry..." (qtd. in Greer 2001, 89). More often, however, the physical appearance of the older woman artist goes unmentioned in early modern life stories, which is 
similarly the case for older male artists, thereby allowing for more focus on inner traits and conduct.

In addition to physical appearance, there were also the issues of emotional vulnerability and distress as the woman artist aged. Like their male counterparts, elder women artists were, on occasion, described as suffering from depression or melancholia. However, this depression was not said to derive from a loss of artistic ability or patronage as was often the case for male artists, but instead was invariably linked to the death of a loved one, such as a spouse or child. The late Renaissance painter Lavinia Fontana (1552-1614) is said to have died of heartbreak after the death of her daughter, who had shown talent as an artist (in Dabbs, 2009, 82-84). Similarly, the Italian painter Giovanna Fratellini (1666-1731) is described as being inconsolable for two years after the death of her son, who also had been following in his mother's footsteps as an artist (in Dabbs 2009, 316). And in a third example, the seventeenth-century Chinese painter Li Yin (16161685 ) is said to have mourned the death of her husband, and the political overthrow of her homeland, for over 30 years, as "with deepest grief, she faced alone a Buddhist eternal lamp night after night" (in Dabbs 2009, 154-156).

In contrast to the biographical emphasis on emotional vulnerability, physical and intellectual decline in old age are generally less-emphasized in life stories of early modern women artists, in comparison to those of their male counterparts. In terms of physical decline, this divergence might be explained by the fact that very few women artists undertook the physically laborious work of fresco painting or large-scale sculpture, which was the undoing of numerous male artists as they aged. Thus, within the twenty-four life stories of women artists 
who lived past the age of 50 that I've gathered to date (Dabbs 2009), only one biographer remarks on a lessening of skill in an artist's advanced age. This occurs in Jan van Gool's life story of Dutch still life painter Rachel Ruysch (1664-1750), where he notes that a work she had recently executed at 84 years of age "will be less" that what had come before (in Dabbs 2009, 270). Yet, what he was comparing the painting to was a still life created when Ruysch was 80 years old, about which he exclaims: "In her house I saw a piece that she had painted in her eightieth year of her life; I was profoundly amazed, so precisely and elaborately was everything executed" (in Dabbs 2009, 270). Indeed, flower painting was a demanding subject that required careful observation and incredible eye-hand coordination, in order to capture and convey a sense of verisimilitude. That Ruysch was apparently still able to paint so effectively into her 80s was indeed a wonder.

One aspect of physical decline that is mentioned relatively more often for aged women artists compared to male artists, however, is vision loss (Dabbs, 2012). In some life stories, women artists are praised as exceptional because their vision was still good in old age: the aforementioned Rachel Ruysch is said by her biographer to have had surprisingly good mental capacities and eyesight even at age 84 (in Dabbs 2009, 270), and Lucia Casalini Torelli (16771762 ) is said to "have always worked vigorously until the end of her days (even to the decrepit age of eighty-five years), always without eyeglasses" (in Dabbs 2009, 395).

In two other cases, however, biographers discuss at more length how women artists faced the consequences of vision loss in their old age. For Rosalba Carriera (1673-1757), vision loss occurred in 1746, when she was in her early 70 s but still actively working in pastels. Despite 
undergoing cataract surgery two times, there was little sustained improvement in Carriera's vision, and by the age of 76, she was completely blind (Mariette 1966, I:331). One of Carriera's last works of art is her haunting Self-Portrait as Tragedy (Fig. 2), which shows a woman transformed by age, with her hair thinning and a somewhat glassy, unfocused left eye. Carriera seems to know that her artistic career will soon come to an end, and thus she assumes the role of tragedy, given the devastating loss of vision for an artist. $^{7}$ Yet, the laurel-leaf wreath and resolute expression suggest that she is not defeated by age, but instead continues to look into the light. One of Carriera's biographers, Francesco Moücke, in fact writes that although she was "deprived of the bodily light [i.e. eyesight], she was just as much enlightened in her mind" (Moücke 1752, IV: 245). In this way, Moücke significantly asserts that Carriera was able to transcend the tragedy of vision loss through her intellective powers, which counters a common perception of the period that women lacked the capacity for intelligence, and in particular the faculty of judgment that was considered crucial to artistic excellence (Huarte 1959, 273, 286; Maclean, 35).

Fig. 2: Rosalba Carriera, Self-portrait as Tragedy, ca. 1746 (Venice: Accademia; Scala/Art $\underline{\text { Resource, NY) }}$

Interestingly, Carriera's intellectual transcendence of vision loss in old age had a precedent in the life of Sofonisba Anguissola (c.1532-1625). A gifted portraitist who, like Carriera, had a successful, international career, Anguissola continued to create art into her old

\footnotetext{
${ }^{7}$ Carriera herself made the initial connection between this self-portrait and the concept of tragedy, as one biographer states that a few years before her blindness she "made her own portrait with a garland of leaves, and having been asked what she meant to signify with that, she responded, that it was Tragedy, and that Rosalba must end tragically, as it was in real life." Antonio Maria Zanetti, Della pittura veneziana, 1771 (Venice: Filippi Editore, 1972) 449.
} 
age. Yet in her 90s the artist went blind, according to her biographer, Raffaele Soprani; significantly, though, he adds that she "at least enjoyed conversing with painters, always discussing the difficulty that they were encountering in art, and offering them very rare and useful documents" (in Dabbs 2009, 117). One artist who confirms that this type of informal instruction took place is Anthony van Dyck, a young Flemish artist who in 1624 had come to Palermo, where Anguissola was then living, due to a portrait commission. Van Dyck's visit to the aged artist was apparently so significant to him that he both visually and verbally recorded what transpired in a sketchbook. He writes that she "has all her memory and is very quick-witted" (in Brown 1983, 82, 84), which indeed must have been amazing to witness in a 96-year-old woman. Yet even more compelling are Van Dyck's comments, later relayed by Soprani in his life story of Anguissola, that "van Dyck used to say that he considered himself very indebted to have conversed with Sofonisba, and confessed to having received much greater instruction from the words of a blind woman, than from the works of the most esteemed painters" (in Dabbs 2009, 117). This indeed was no faint praise, for van Dyck had studied paintings by such artists as Titian and Rubens, yet here he is crediting a blind old woman with having been the more influential teacher. Was this just rhetorical hyperbole, a not uncommon feature of early modern biographical writing? If so, it is unprecedented in regards to a woman artist; and even if the comment is potentially exaggerated, Soprani's comments demonstrate that it was possible for the woman artist to be seen as a sage mentor who could transcend the career-ending fate of blindness through her active intelligence. 
Rosalba Carriera and Sofonisba Anguissola are two women artists whose biographical characterizations, I believe, place them in the exemplary category of "heroic old age" through their inspirational demonstrations of emotional tenacity and intellectual acuity in the face of blindness. My interpretation of their positive exemplarity thus dovetails with more recent research in ageing studies that supports an alternative view of old women in the early modern period in which they are shown to exhibit wisdom, creativity, authority and other forms of agency (Botelho 2013, 306). To demonstrate that this type of positive characterization of the elder woman artist was indeed not an anomaly, I would like to conclude with a slightly later example, that of the American sculptor Patience Wright (1725-1786). Following the death of her husband in 1769, Wright needed to support herself and her four children, and given the lack of art materials and training in the colonies she turned to the domestic medium of wax, which she taught herself to sculpt. Eventually, Wright, along with her sister, established the first travelling waxworks exhibit in America. However, with little art patronage in colonial times, especially for wax busts, Wright and her family moved to London in 1772, where she set up a studio at the age of 47. The astonishing verisimilitude of her figures, as seen in the lone surviving statue of William Pitt (London, Westminster Abbey), led to a flurry of patronage, including that of King George III and Queen Charlotte (Sellers 1976). Nevertheless, Wright, who very atypically for a woman was working in the medium of sculpture, was at times portrayed negatively, or at best ambivalently, due to her transgression of normative gender roles in the eighteenth century. This can be seen in an illustration of the artist which accompanied a relatively-lengthy life story of Wright published in The London Magazine in 1775 (Fig. 3). At first glance, we see Wright as a 
respectably dressed, older matron who is rather regally depicted in profile; but then our gaze is disrupted by the puzzling sight of a middle-aged male figure seemingly emanating from Wright's mid-section, and who gazes up at her. This rendering may reference Wright's unusual "birthing" technique for creating her wax portrait busts in which she would partially model the wax between her thighs to maintain its malleability (Dabbs 2009, 424). While the life story's author claims that the illustration is an "exact likeness" of Wright, the inclusion of the male figure results in an image of the elder woman artist that is provocative and potentially scandalous, yet not uncommon in popular print images of "transgressive" women sculptors in the eighteenth century (Dabbs $2009,424)$.

Fig. 3: Anonymous, Portrait of Patience Wright, from the London Magazine (Nov. 1775), p. 557.

However, the life story that accompanies this illustration of Wright is much less provocative, and in fact is an extraordinarily positive characterization of this strong-willed, older woman. Published some 11 years before her death, the anonymous writer approaches his subject from a respectful perspective, given that Wright, now age 50, was in her last stage of life. The biographer not only has high praise for Wright's artistic skills, but also her unblemished character, so as to deflect any rumours of inappropriate behaviour. Yet he particularly emphasizes Wright's intellect, lauding her "sense and argument on public subjects, [such] that the most learned men may draw instruction from the keenness of her observations, and the satire of her language. She is a kind of exotic prodigy, and appears, like Pallas [Athena] to have come forth complete from the head of Jove" (in Dabbs 2009, 428-49). In other passages, the biographer notes Wright's intelligence by referencing her "genius," a trait rarely used in relation to women 
artists due to their perceived physiological difference from men (Dixon 2013, 13). He visually reinforces this quality by describing Wright, even as an older woman, as having "an eye of that quick and brilliant water, that it penetrates and darts through the person it looks on..." (in Dabbs 2009, 428). Although the biographer's verbiage can seem excessively embellished to the modern reader, his characterization finds a striking echo in a slightly later portrait of Wright (Fig. 4). Now approximately 57 years of age, we see the older creator apparently preparing to work as she leans forward, with a modelling apron over her lap. Wright's head is actively turned and her eyes cast upwards, allowing her face to be fully illuminated by an unseen light source, thus effectively suggesting the work of the mind that preceded the work of the hands. Although Wright appears more aged than in Fig. 3, we are still presented with an artist who is capable and active, both physically and mentally.

Fig. 4: Robert Edge Pine (attrib.), Portrait of Patience Lovell Wright, c. 1782 (National Portrait Gallery, Smithsonian Institution)

As these examples of Wright, Anguissola, Carriera, and Ruysch have shown, the elder woman artist in the early modern period was in no way invisible; it is only our limited modern vision that has veiled them from view. Not only have art historical studies of older artists minimized the presence of the female creator, but recent books on the history of self-portraits more often depict older male artists in comparison to older female artists. ${ }^{8}$ Even books focusing on women artists continue to be predominantly illustrated with portraits of younger, rather than

\footnotetext{
${ }^{8}$ In James Hall's The Self-Portrait: A Cultural History (London: Thames \& Hudson, 2014) of the approximately 100 self-portraits of men, 19 (or roughly 20\%) are of male artists over 50 years of age, while only one out of nine selfportraits of women depict a female over 50. An even greater disparity is found in Laura Cumming's A Face to the World: On Self-Portraits (London: Harper Press, 2009): of the 71 self-portraits by male artists, some 24 are of men over 50 , and of the 11 self-portraits by women, none are over 50 years of age.
} 
older women; to cite one example, Jordi Vigué's Great Women Masters of Art (2002) includes eleven images of older women artists out of a total of 85 portraits. ${ }^{9}$ When will "greatness" for the female artist no longer require a youthful, beautiful portrayal? Can it not be evidenced in the abilities of Wright and Ruysch to continue creating works of art into their later years? Or Anguissola's desire to instruct young artists into her 90s? Or Carriera's effort to transcend the loss of her eyesight with courage and fortitude? It is only when we fully investigate the lives of women artists, as has been done for many male artists, that we will recognize that their achievements go far beyond the surface beauty of youth. There is so much more we can learn about, and from, these elder creators.

\section{Works Cited}

Bernini, Domenico. 2011. The Life of Gian Lorenzo Bernini. Translated by Franco Mormando. University Park, PA: Penn State University Press.

Boccaccio, Giovanni. 2001. Famous Women. Translated by Virginia Brown. Cambridge/London: Harvard University Press.

Botelho, Lynn. 2013. "Old Women in Early Modern Europe." In The Ashgate Research Companion to Women and Gender in Early Modern Europe, edited by Allyson M. Poska, Jane Couchman, Katherine A. McIver. 297-315. Burlington, VT: Ashgate.

Brown, Christopher. 1983. Van Dyck. Ithaca, NY: Cornell University Press.

Campbell, Erin J. 2002. "The Art of Aging Gracefully: the Elderly Artist as Courtier in Early Modern Art Theory and Criticism." Sixteenth-Century Journal 33: 321-331.

Castiglione, Baldesar. 1967. The Book of the Courtier. Translated by George Bull. New York: Penguin.

Chadwick, Whitney. 2012. Women, Art, and Society. London: Thames \& Hudson.

\footnotetext{
${ }^{9}$ In another case, Whitney Chadwick's Women, Art, and Society (London: Thames \& Hudson, 2012) includes three portraits of women artists past the age of 50, out of a total of 29. In compiling these statistics, we continued to use the early modern "threshold" of fifty years of age to identify who, whether male or female, might be considered "old." I would like to thank research assistant Sophia Chadbourne for her work on collecting this data.
} 
Chapman, H. Perry. 2013. "Self-Portraiture 1400-1700.” In A Companion to Renaissance and Baroque Art, edited by Babette Bohn and James M. Saslow. 189-209. Hoboken: Wiley.

Cumming, Laura. 2009. A Face to the World: On Self-Portraits. London: HarperPress.

Dabbs, Julia K. 2008. "Anecdotal Insights: Changing Perceptions of Italian Women Artists in $18^{\text {th }}$-Century Life Stories." Eighteenth-Century Women 5: 29-51.

Dabbs, Julia K. 2009. Life Stories of Women Artists 1550-1800: An Anthology. Burlington, VT: Ashgate.

Dabbs, Julia K. 2012. "Vision and Insight: Portraits of the Aged Woman Artist, 16001800." Occasion: Interdisciplinary Studies in the Humanities (Stanford University/Arcade) 4 (May 31 2012). Web. http://arcade.stanford.edu/occasion/visionand-insight-portraits-aged-woman-artist-1600-1800.

Dixon, Laurinda. 2013. The Dark Side of Genius: The Melancholic Persona in Art, ca. 1500-1700. University Park, PA: The Pennsylvania State University Press.

Greer, Germaine. 2001. The Obstacle Race: The Fortunes of Women Painters and Their Work. New York: Tauris Parke.

Hall, James. 2014. The Self-Portrait: A Cultural History. London: Thames \& Hudson.

Huarte, Juan. 1959. Examen de ingenios: The Examination of Men's Wits (1594). Translated by Richard Carew. Gainesville: Scholars' Facsimiles \& Reprints.

Maclean, Ian. 1983. The Renaissance Notion of Woman: A Study in the Fortunes of Scholasticism and Medical Science in European Intellectual Life. Cambridge: Cambridge University Press.

Mariette, P.J. 1966. Abecedario. Paris: F. de Nobele.

Moücke, Francesco. 1752-1762. "Rosalba Carriera." In Serie di ritratti degli eccellenti pittori dipinti di propria mano che esistono nell'Imperial galleria di Firenze. Florence.

Perlingieri, Ilya. 1992. Sofonisba Anguissola: The First Great Woman Artist of the Renaissance. New York: Rizzoli.

Ridolfi, Carlo. 1996. The Life of Titian. Translated by Julia Conaway Bondanella. University Park, PA: Penn State UP, 1996.

Rubin, Patricia. 1990. "What Men Saw: Vasari's Life of Leonardo da Vinci and the Image of the Renaissance Artist." Art History 13:34-46. 
Sellers, Charles C. 1976. Patience Wright: American Artist and Spy in George III's London. Middleton, CT: Wesleyan University Press.

Sohm, Philip L. 2007. The Artist Grows Old: The Aging of Art and Artists in Italy, 15001800. New Haven/London: Yale University Press.

Vasari, Giorgio. 1996. Lives of the Painters, Sculptors and Architects. Translated by Gaston du C. de Vere. 2 vols. New York: Knopf.

Vigué, Jordi. 2002. Great Women Masters of Art. New York: Watson-Guptill.

Zanetti, Antonio Maria. 1771/1972. Della pittura veneziana. Venice: Filippi Editore. 